\title{
Economics of managing mesquite in north Texas: a sensi- tivity analysis
}

\author{
W. R. TEAGUE, R.J. ANSLEY, U.P. KREUTER, W.E. PINCHAK, AND J.M. McGRANN
}

Authors are associate professors, Texas Agricultural Experiment Station, P.O. Box 1658, Vernon, Tex. 76385, assistant professor Department of Rangeland Ecology and Management, Texas A\&M University, College Station, Tex. 77843-2126, associate professor, Texas Agricultural Experiment Station, P.O. Box 1658, Vernon, Tex.76385, and professor Department of Agricultural Economics, Texas A\&M University, College Station, Tex. 77843-2124.

\begin{abstract}
This paper presents a comparative simulation analysis of the economics of prescribed fire and aerially applied root-killing herbicide treatment as methods for maintaining livestock productivity on rangeland in the Texas Rolling Plains. A "no-treatment" scenario is used as the base for comparison. In almost all the simulated scenarios both herbicide application and prescribed burning were economically feasible since net present values were $>0$ and benefit/cost ratios were $>1$. However, the net present values for prescribed fire were much higher that those for the herbicide treatment even with a lower increase in carrying capacity with burning. The cost of herbicide would have to be less than half the current cost of $\$ 57 \mathrm{ha}^{-1}$ before it would be economically competitive with fire in controlling mesquite. If cattle numbers were not increased after treating brush, burning had an even greater net present value and benefit/cost ratio advantage over herbicide treatment than if cow numbers were increased after treatment. Even if fences have to be constructed to implement adequate deferment for burning, the net present value and benefit/cost ratios of the fire option were higher than those for herbicide scenarios. This analysis indicates that there is an economic advantage to using fire wherever possible, and use of herbicides is restricted to those instances when fine fuel amount is $<1,700 \mathrm{~kg}$ $\mathrm{ha}^{-1} \mathrm{yr}^{-1}$ when fire is not a viable option. The analyses indicate the economic response is most sensitive to the treatment effect on wildlife income.
\end{abstract}

Key Words: Brush management, bioeconomics, natural resource accounting, prescribed burning, root-killing herbicide

In the southwestern U.S.A., honey mesquite (Prosopis glandulosa Torr.) dominates many rangelands reducing herbaceous production and interfering with livestock foraging and management. The accelerated increase of woody plants into grasslands has been attributed to overgrazing and lack of fire (Scifres 1980). Traditionally, mesquite rangelands have been managed for beef cattle production but increasingly income from wildlife can equal or exceed that from livestock on many ranches (Bernado et al. 1994). The cost to control mesquite, the cost of follow-up maintenance treatments and the net earnings of the treated versus nontreated land determine the economics of brush control. Previous

We wish to thank David Engle for kindly reviewing an earlier draft of the manuscript. Manuscript accepted17 Nov. 00.

\section{Resumen}

Este artículo presenta un análisis de simulación comparativo del aspecto económico del fuego prescrito y los tratamientos de aplicación aérea de herbicida como métodos para mantener la productividad del ganado en pastizales de la región de las Planicies Onduladas de Texas, se uso un escenario "Sin Tratamiento" como base de comparación. En casi todos los escenarios simulados la aplicación de herbicida y el fuego prescrito fueron económicamente factibles ya que los valores netos presentes fueron $>0 \mathrm{y}$ las relaciones beneficio/costo fueron $>1$. Sin embargo, los valores netos presentes para el fuego prescrito fueron mucho mayores que los del tratamiento de herbicida, aun con un menor incremento en la capacidad de carga debida al fuego. El costo del herbicida tendría que ser menos de la mitad del costo actual de $\$ 57 \mathrm{ha}^{-1}$ antes de que fuera económicamente competitivocon el fuego para controlar mezquite. Si los números de ganado no se incrementaron después de tratar los arbustos, la quema aun tendría un mayor valor neto presente $y$ una ventaja en la relación beneficio/costo sobre el tratamiento con herbicidas que si los números de ganado se incrementaran después del tratamiento. Aun, si se tiene que construir cercos para implementar un diferimiento adecuado de la quema, el valor neto presente y la relación beneficio costo del fuego fueron mayores que las de los escenarios con herbicidas. Este análisis indica que hay una ventaja economica para usar el fuego cuando sea posible, $y$ el uso de herbicidas se restringe a aquellas ocasiones cuando la cantidad de combustible fino es $<$ de $1,700 \mathrm{~kg} \mathrm{ha}^{-1}$ año-1, cuando el fuego no es una opción viable. El análisis indica que la respuesta económica es mas sensitiva al efecto del tratamiento en el ingreso por fauna silvestre.

research by Vantassell and Conner (1986) recognized the response from treatment but ignored the fact that if brush is not controlled it increases. This further reduces herbage production, increases cattle management costs, and may reduce wildlife earning capacity.

This paper presents the difference in net present value and benefit/cost $(\mathrm{B} / \mathrm{C})$ ratios for treating mesquite using 2 of the most cost-effective brush management treatments in the Rolling Plains of Texas: prescribed burning at an interval of 5--7 years and aerial spraying with a root-killing herbicide that has a treatment life of approximately 20 years (Scifres and Hamilton 1993, Ueckert et al. 1999). The biological information used in these calculations was collected from small-scale independent projects in the 
Rolling Plains of Texas. Since this database is incomplete, a sensitivity analysis was conducted to identify the relative importance of the different biological and economic parameters needed to develop biologically and economically sustainable management systems. The analysis relates to ranches that are 1,600 to 20,000 ha in size with mesquite that needs a brush reduction treatment. The costs and benefits of carrying out particular management actions are compared with the value in lost productivity due to not treating the brush.

\section{Methods and Procedures}

\section{Economic model}

The economic efficiency of treating brush with fire or herbicide was calculated by determining the differences in net present value and benefit/cost ratio of treated vs. untreated land over a 30-year period. A project is considered economically feasible if net present value $\geq 0$ (i.e. discounted returns exceed discounted costs). Treatments with higher net present value ratios are considered economically superior (Workman 1986). The benefit/cost ratio was calculated by determining the difference in present value of returns (benefits) divided by the present value of treatment costs and maintenance. The ratio must be greater than 1 for the treatment to be economically feasible.

The change in land value is not taken into account because land values are often unrelated to productivity and are frequently driven by speculative investors. Calculation of net present value was as follows:

$$
\mathrm{NPV}=\sum_{i=0}^{n} R_{i} /(1+d)^{I}
$$

Where $R=$ future net value

$d=$ discount rate or rate of return

$n=$ planning horizon

$i=$ years

In the economic model, carrying capacity was calculated for each year of the analysis by multiplying average carrying capacity per hectare by the number of hectares. The total lease value was estimated by multiplying the carrying capacity by the lease rate. The net present value of each treatment was calculated using a 30-year time horizon of treatment benefits and costs and a specified discount rate. The analyses were based on the assumption that income and operating costs are incurred at the end of each year, with the exception of initial treatment costs, which were assumed to occur at the beginning of year 1 . The analyses were conducted using a spreadsheet program developed by McGrann et al. (1998). Costs of the treatment and maintenance were entered into the spreadsheet, as well as any associated improvements (fencing, water, facilities, etc.), using data from the Waggoner Experimental Ranch in north Texas $\left(33^{\circ}\right.$ $\left.50^{\prime} \mathrm{N}, 99^{\circ} 5^{\prime} \mathrm{W}\right)$. Since net present value and benefit/cost ratio estimates are correlated, we discuss only the net present value of each treatment analyzed. However, in the associated tables, benefit/cost ratios are also presented to accommodate preferences for either measure. Analysis showed little sensitivity to a range of discount rates so a rate of $5 \%$ was used. We used the current rate for leased cow-calf ranchland in the Rolling Plains of Texas of $\$ 90 \mathrm{Au}^{-1}$ year $^{-1}$ (Stan Bevers, Extension Economist, TAEX, Vernon, Tex., personal communication).

\section{Grass production with increasing brush}

Treatment response and longevity have a major effect on the economic efficacy of brush clearing. Herbage growth beneath mesquite changes little until a threshold is reached beyond which herbage growth is severely reduced (Dahl et al. 1978). An increase in herbage with clearing was only obtained if pre-treatment mesquite cover was $30 \%$ or more (Dahl, et al. 1973). The magnitude of herbage growth response following clearing also differed markedly depending on climatic conditions, the productive potential of the soil and the herbage species composition or range con- dition at the time of treatment (Dahl et al. 1973, Scifres and Polk 1974, McDaniel et al. 1978, 1982, Brock et al. 1978, Gibbens et al. 1986).

Recent work in north Texas has defined the long-term regrowth and invasion of mesquite following a root-killing herbicide and the resulting reduction of herbage production as mesquite aerial cover increased over a 30-year period, summarized in Fig. 1. Mesquite cover was estimated to increase at a rate of 1 percentage unit per year (Ansley et al. 2001). Carrying capacity was calculated using the percentage reduction in herbage production due to mesquite from McMullen (2000) and the mean herbage production from 5 years of field data in north Texas (Teague et al. 1999). Allocating 25\% of peak standing crop at $12 \mathrm{~kg} \mathrm{Au}^{-1}$ day $^{-1}$, these calculations give an average carrying capacity for Waggoner Experimental Ranch of approximately 12.1 ha $\mathrm{AUY}^{-1}$. The Waggoner Experimental Ranch is stocked at 13.4 ha $\mathrm{AUY}^{-1}$ for average precipitation years (Teague et al. 1999). This research area comprises approximately equal proportions of shallow-clay soils that have very low amounts of mesquite and clay-loam soils that support significant mesquite cover. The shallow-clay soils currently have a carrying capacity of approximately 15.8 ha $\mathrm{AUY}^{-1}$ (Table 1). The clay-loam soils have a carrying capacity of approximately 8.9 ha $\mathrm{AUY}^{-1}$ when clear of mesquite and 13.4 ha $\mathrm{AUY}^{-1}$ with $30 \%$ aerial cover of mesquite.

The assumed changes in productivity (carrying capacity) with time following no-treatment and treatment are presented for prescribed fire (Fig. 2) and are based

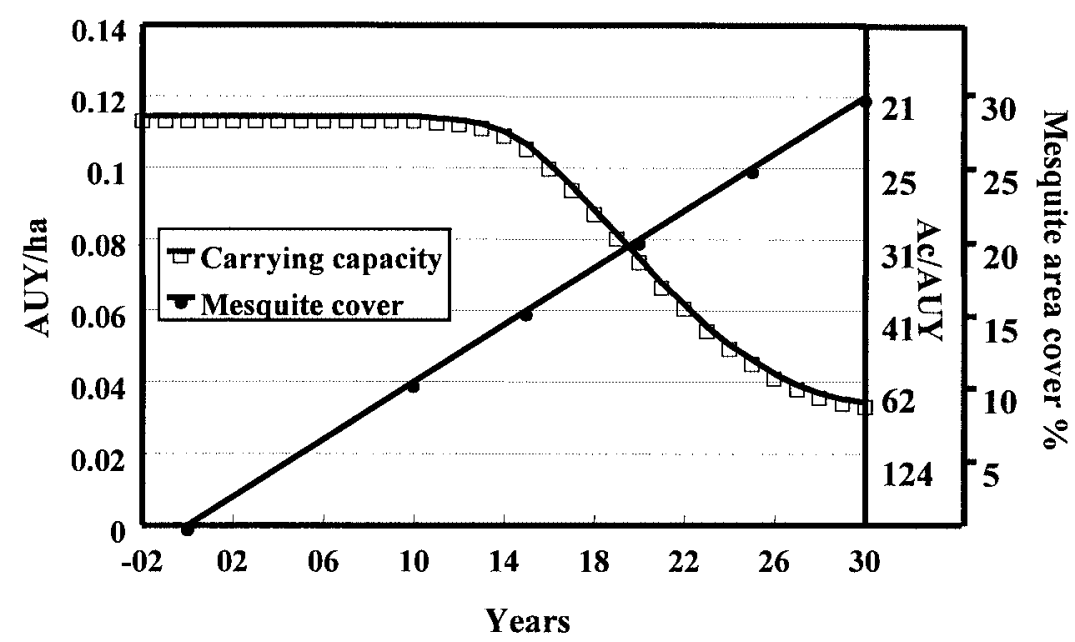

Fig. 1. Carrying capacity decline with time from a completely cleared situation, due to increasing mesquite brush on the Waggoner Experimental Ranch (from McMullen 2000, Ansley et al. 2001). 
Table 1. Parameter values used in the economic analyses.

\begin{tabular}{|c|c|c|c|}
\hline \multicolumn{2}{|c|}{ Parameter } & \multirow{2}{*}{$\frac{\text { Herbicide }}{50}$} & \multirow{2}{*}{$\frac{\text { Fire }}{50}$} \\
\hline 1 & Area to be treated $(\%)$ & & \\
\hline 2 & Mesquite aerial cover before treatment $(\%)$ & 30 & 30 \\
\hline 3 & Discount rate $(\%)$ & 5 & 5 \\
\hline 4 & Income tax rate $(\%)$ & 15 & 15 \\
\hline 5 & Capital gains tax rate $(\%)$ & 20 & 20 \\
\hline 6 & Wildlife income $\left(\$ \mathrm{ha}^{-1}\right)$ & 7.41 & 7.41 \\
\hline 7 & Treatment longevity (years) & 20 & 7 \\
\hline 8 & Cost $\left[\$ \mathrm{ha}^{-1}\right]$ Initial treatment & 56.81 & 6.18 \\
\hline & Follow-up treatments & 6.18 & 6.18 \\
\hline 9 & Carrying capacity untreated area (ha AUY-1) * & 15.8 & 15.8 \\
\hline 10 & Carrying capacity of treated area before treatment ( $30 \%$ mesquite) $)^{* *}$ & 13.4 & 13.4 \\
\hline 11 & Carrying capacity of treated area after treatment (10\% mesquite) $)^{* *}$ & 8.7 & 10.9 \\
\hline
\end{tabular}

*Land that has shallow-clay soil of relatively low productivity for herbage and very low amounts of brush. Carrying capacity has been calculated by allocating $25 \%$ of peak standing crop @ $12 \mathrm{~kg} \mathrm{hd}^{-1} \mathrm{day}^{-1}$ using 5 years of data from Teague et al. (1999).

**Land that has clay-loam soils of moderately productive soils where the major presence of mesquite occurs. Carrying capacity has been calculated as above.

on results for north Texas in which topkilling treatment effects lasted 6 to 7 years (Heitschmidt et al. 1986). We assume that fire would need to be applied once every 7 years to suppress mesquite regrowth. Grass growth the season after fire was assumed to be at pretreatment levels. One scenario we considered was that the peak production after year 1 increased with repeated fires as illustrated in Fig 2. We also considered a reduced response in which the lower peak production following the first burn in Fig. 2 occurred after all burns in the 30 year period. We also considered scenarios with no response delay and burning every 5 years compared to every 7 years.

Twenty-year and 30-year longevity scenarios are considered following herbicide application with no follow-up treatment (Fig. 3) based on data in which rootkilling treatment effects lasted up to 20 years (Ansley et al. 2000). In addition, 2 alternative scenarios are considered following herbicide application with the 20year return to pretreatment levels (Fig. 4). These include follow-up treatment with prescribed fire 16 or 20 years after the initial herbicide application.

The parameter values used for the majority of scenarios are presented in Table 1. The current recommendation for herbicide application to control mesquite on large ranches is to aerially broadcast $0.28+0.28 \mathrm{~kg} \mathrm{ha}^{-1}$ Clopyralid + Triclopyr herbicide at a cost of $\$ 57 \mathrm{ha}^{-1}$ (Ueckert et al. 1999). Although technology has been developed to treat individual mesquite plants at a much lower cost of $\$ 30 \mathrm{ha}^{-1}$ for densities of 1,000-1,200 plants $\mathrm{ha}^{-1}$ (Ueckert et al. 1999), this method of application is generally applicable only for smaller scale properties and was thus not used for these large ranch simulations.
Costs of burning in north Texas, including the cost of creating firebreaks and preburning blacklines range from $\$ 6$ to $\$ 7 \mathrm{ha}^{-1}$ (Ansley et al. 1999). However, it is possible to burn at lower cost if pre-burn preparations only include the cost of grading the perimeter of the area to be burned. For most scenarios a retreatment interval of 7 years is used for burning but in 1 scenario a retreatment interval of 5 years is considered. The same cost ha ${ }^{-1}$ was used for each repeat burn. We assume pre- and postburn deferment.

All scenarios assume that cattle numbers will be increased according to the increase in herbage production following brush treatment. However, cattle numbers are not increased on some ranches. In such cases, individual cow production would increase owing to the increased amount of

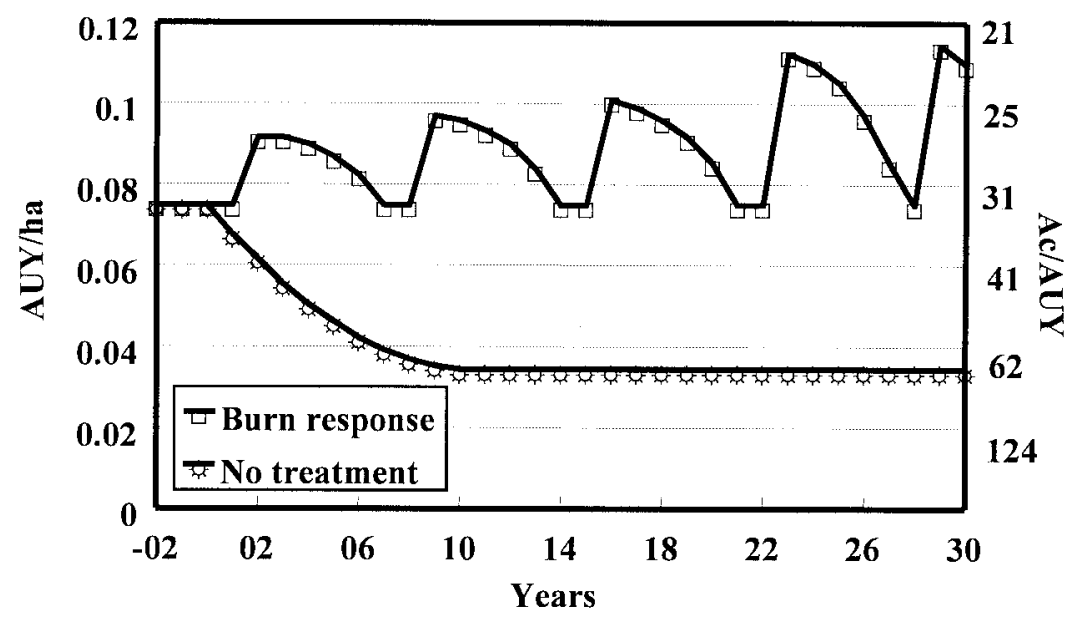

Fig. 2. Carrying capacity of treated compared to untreated mesquite using prescribed burning. Grass growth the season after fire was assumed to be at pretreatment levels. The peak production after year 1 was assumed to increase with repeated fires.

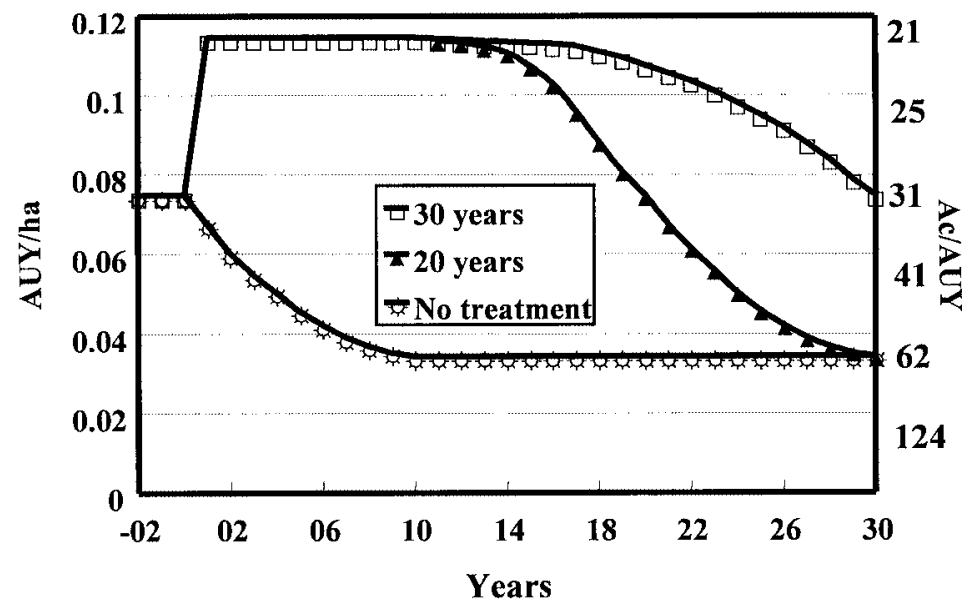

Fig. 3. Carrying capacity of treated compared to untreated mesquite using a root-killing herbicide with treatments lasting 20 - and 30 -years before pretreatment levels are reached. 


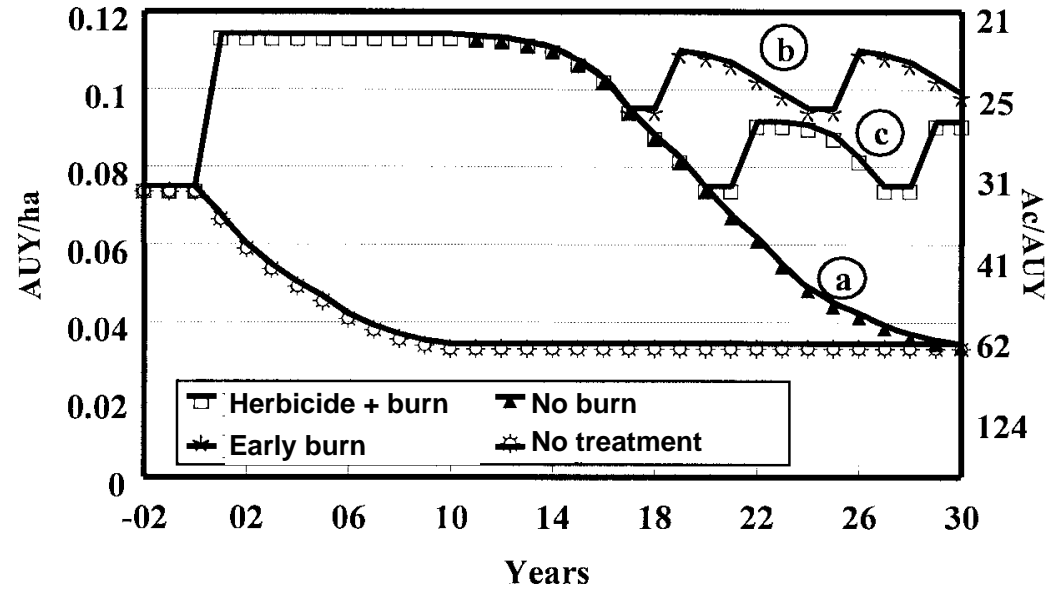

Fig. 4. Carrying capacity of treated compared to untreated mesquite using a root-killing herbicide followed by different post-herbicide treatment prescribed burn scenarios: (a) no burning (b) burning after 16 years and (c) burning after 20 years.

herbage per cow as demonstrated by Bement (1969). The option of not increasing cow numbers following brush treatment was compared to the option of increasing cow numbers to use extra herbage produced using increased individual cow performance of 5 and $10 \%$ following treatment if cow numbers remained static. This is based on annual fluctuations in animal performance of 5$10 \%$ measured in north Texas due to varying amounts of herbage produced in response to climatic variability and different stocking rates (Heitschmidt et al. 1986, Teague et al. 1999). We assume that using light to moderate stocking rates will prevent having to reduce stock numbers in times of serious drought.

\section{Factors affecting the efficacy of herbicides and burning}

Uncertainty exists about how effective fire can be relative to herbicide application in reducing the problems associated with mesquite. This sensitivity analysis aims at determining which factors and combinations of factors significantly influence the relative economic value of these alternative treatments. Burning has a significant effect on environmental conditions, which lasts a number of years (Wright and Bailey 1982). The removal of surface and standing litter by fire and the blackened soil surface result in higher soil temperature. This promotes growth earlier in spring and increases soil moisture evaporation, both of which reduce soil moisture more rapid1y. The increase in herbage quality and increase in number of species that are consumed after burning (Wright and Bailey 1983) counteract the reduced amount of herbage produced. The net result is that secondary productivity can be increased on burned relative to unburned areas when favorable growing conditions prevail (Angell et al. 1986, Svejcar 1989). However, primary and secondary productivity are reduced on burned areas when growing conditions are below average (Wright and Bailey 1982). We do not know how many years these areas take to recover. However, in a study in the Rolling Plains of Texas with rotational grazing, the number of grazing days was doubled in burned pastures, compared to non-burned pastures, in years 2 and 3 after burning (Teague et al. 1999) when burning was followed by a drought year.

Fire generally results in patchier and less complete canopy top-kills than broadcast herbicide application, resulting in less reduction in brush aerial cover and lower increase in herbage production with prescribed fire (Hamilton et al. 1981). The longevity of treating mesquite with fire appears to be similar to that reported above for top-killing herbicides. In the case of mesquite in the Rolling Plains, retreatment is necessary after approximately 6 to 7 years, based on work by Heitschmidt et al. (1986), but retreatment may be needed after only 5 years since few mesquite are killed even with repeated fires (Ansley et al. 1998).

Pre- and post-burn deferments are necessary to minimize the negative environmental effects of fire and to provide adequate amounts and continuity of grass fuel (Scifres and Hamilton 1993, Teague et al. 1997). One-herd multiple-pasture systems facilitate such deferment and allow the use of fire in non-drought years at a frequency of 4 to 6 years to internalize the cost of treating the brush by avoiding the cost of grazing extra land. Most ranches would be able to implement at least a 4-pasture, 1herd system of management without incurring extra fencing costs by consolidating herds. However, scenarios that do require extra fencing to implement deferment are considered in this economic analysis to account for this possibility. The economic consequences of adding electric or regular 5 -wire fencing in year 1 are considered using costs of $\$ 210$ and $\$ 2,100$ per kilometer of fence, respectively. In addition, assuming that $1 / 4$ of the grazing unit will be deferred and burnt, approximately $10 \%$ of total grazing days in a year are lost due to deferment. This would result in a small loss in animal productivity since the effective stocking rate would be heavier and animals would not perform as well. Burning $1 / 8$ of the grazing unit would result in losing $5 \%$ of total grazing days and would be managed for with a burning interval of 7-8 years. We consider a scenario in which $10 \%$ fewer animals are stocked to determine the economic consequences of decreasing animal numbers to account for the days of lost grazing. We assume that no post-treatment deferment is necessary following herbicide application based on Ueckert et al. (1999).

\section{Wildlife and brush clearing}

Wildlife is an increasingly important addition to ranch income (Bernado et al. 1994). Wildlife requires suitable cover and food plants to satisfy habitat requirements. For example, optimal habitat for bobwhite quail and white-tailed deer includes about 10-20\% brush cover (Lehman 1984, Guthery 1996, Teer 1996). Thus any management practice that influences habitat for these species will change income derived from them. Herbicides and fire affect deer and quail habitat differently. While complete clearing with herbicides may be desirable for livestock production it would significantly reduce the value of the area for deer and quail. However, patterns of clearing can be implemented using herbicides that optimize cover requirements for specific species (Fulbright and Guthery 1996, Koerth 1996). After herbicide treatment aimed at reducing brush, forb populations important for deer and quail are generally suppressed for at least 1 growing season. However, forb abundance can improve significantly in treated areas in subsequent years (Scifres and Koerth 1986, Koerth 1996).

Burning can have a positive effect on wildlife habitat for some species. Burns 
improve plant composition and the quality of feed for many wildlife species and thus attract wildlife (Guthery 1996, Teer 1996). Early winter burning has been shown to increase forbs that are significant to whitetailed deer (Hansmire et al. 1988). In addition, at the landscape level the patchy nature of fires leaves islands of cover that enhance habitat. Woody plants also regrow rapidly after top-kill by fire and provide cover more rapidly than rootkilling herbicide applications. Small amounts ( $<15 \%$ cover) of woody plant cover interfere little with livestock management for 3 to 4 years after a burn and provide relatively little competition with herbage production (McMullen 2000). The changes in grazing management required to provide pre- and post-burning deferment have also been shown to improve habitat for wildlife. For example, at the Sonora Experiment Station in south Texas, White-tailed deer preferred a 7-pasture-1herd cattle grazing rotation system over the 4-pasture-3-herd deferred and continuous graze systems (Reardon et al. 1978).

The consequences of increasing or decreasing income from wildlife are considered using a wildlife income of $\$ 7.41$ ha- 1 for the whole management unit. This is the wildlife income level used by Thurow et al. (2000) for brush at 5 to $15 \%$ aerial cover. Wildlife income is increased or decreased to the upper $\left(\$ 12.35 \mathrm{ha}^{-1}\right)$ and lower $\left(\$ 2.47 \mathrm{ha}^{-1}\right)$ levels likely to be encountered in north Texas (Dr. Dale Rollins, Wildlife Extension Specialist, TAEX, San Angelo, Tex., personal communication) on the treated portions of the management unit to simulate positive or negative effects on wildlife income that may occur with either method of treating the brush.

\section{Results and Discussion}

In almost all the simulated scenarios both herbicide application and prescribed burning were economically feasible since net present values were $>0$ and benefit/cost ratios were $>1$. However, the net present values for prescribed fire were much higher than those for the herbicide treatment (Table 2). The lowest net present values were for the herbicide with herbicide follow-up treatment. When the herbicide with a follow-up burn after 20 years was compared to the burn with a delayed response, net present value remained much higher for the prescribed burn treatment. When the longevity of the herbicide was assumed to be 30 years, net
Table 2. Consequence of treating mesquite with root-killing herbicides or prescribed fire on net present value (NPV) and benefit/cost $(B / C)$ ratio under different management scenarios.

\begin{tabular}{|c|c|c|c|c|c|c|}
\hline \multirow[t]{2}{*}{ Treatment } & \multirow{2}{*}{$\begin{array}{l}\text { Treatment } \\
\text { Longevity }\end{array}$} & \multirow[t]{2}{*}{ Scenario Description } & \multicolumn{2}{|c|}{ Treatment Cost } & \multirow[t]{2}{*}{ NPV } & \multirow{2}{*}{$\begin{array}{r}\mathrm{B} / \mathrm{C} \\
\text { Ratio }\end{array}$} \\
\hline & & & Initial & Follow-up & & \\
\hline & & & \multicolumn{3}{|c|}{ - $\left(\$\right.$ ha $\left.^{-1}\right)$} & \\
\hline \multirow[t]{5}{*}{ Herbicide } & 20 years & No follow-up burn & 56.81 & 0 & 12.2 & 2.3 \\
\hline & 30 years & No follow-up & 56.81 & 0 & 14.8 & 2.5 \\
\hline & 20 years & Follow-up burns after 16 years & 56.81 & 6.18 & 13.6 & 2.3 \\
\hline & 20 years & Follow-up burns after 20 years & 56.81 & 6.18 & 13.2 & 2.3 \\
\hline & 20 years & Herbicide after 20 years & 56.81 & 56.81 & 11.0 & 1.8 \\
\hline \multirow[t]{5}{*}{ Burn } & 7 years & Response delayed 1 year & 6.18 & 6.18 & 18.0 & 6.8 \\
\hline & 7 years & Response not delayed & 6.18 & 6.18 & 18.5 & 7.0 \\
\hline & 7 years & $10 \%$ fewer animals & 6.18 & 6.18 & 16.2 & 6.8 \\
\hline & 7 years & Reduced response & 6.18 & 6.18 & 17.3 & 6.6 \\
\hline & 5 years & Response not delayed & 6.18 & 6.18 & 15.7 & 4.4 \\
\hline
\end{tabular}

present value increased relative to the 20year longevity but the net present values for prescribed fire were still higher.

Net present values of burn scenarios which considered reduced stock numbers and reduced carrying capacity increase following fire were still much higher than those of the herbicide with follow-up burn treatments (Table 2). With the scenario of no delayed response following a burn, a slightly higher net present value was realized compared to the delayed response. The scenario of burning at 5-year intervals lowers net present value values relative to the 7-year burn interval but still has greater net present value than the herbicide scenario. The option of burning 16 years rather than 20 years after herbicide application did not increase net present values. In practice, this strategy would probably be advisable since there would be a greater certainty of applying effective burn treatments with lower levels of brush. The longer retreatment is delayed the higher the amount of brush and the lower the amount of fuel to carry fire to achieve adequate brush control. This would be accentuated during drought years.

The main reason for the low net present value values when using herbicide is the high initial cost of application. Low net present values were associated with early, large capital expenditures compared to the same amount spent over the length of any period under examination. The high net present values for prescribed burning were a result of a number of small investments spread over the 30-year period compared to the large single investment at the beginning for herbicide application.

The option of not increasing cow numbers after treating mesquite is considered in Table 3. All scenarios were economically feasible and all net present values were greater for burning than herbicide scenarios. In addition, with the herbicide options, the net present values for maintaining constant cow numbers were 68 to $72 \%$ those of the option for increasing cow numbers. In contrast, with the burning options, the net present values for maintaining constant cow numbers were 89 to $92 \%$ those for increasing cow numbers. Therefore, if cow numbers are not increased after treating brush, burning has an even greater economic advantage over herbicide treatment than if cow numbers are increased after treatment.

It is important to indicate that the results
Table 3. Net present value (NPV) and benefit/cost $(\mathrm{B} / \mathrm{C})$ ratio consequences of treating mesquite with root-killing herbicides or prescribed fire under different management scenarios: (1) increasing cow numbers according to the increase in herbage production or (2) not changing cow numbers, and thereby increasing production per cow by 5 or $10 \%$.

\begin{tabular}{llccc}
\hline \hline Treatment & Scenario Description & $\begin{array}{c}\text { Increase in } \\
\text { Production } \\
\text { Per cow }\end{array}$ & NPV & $\begin{array}{c}\text { B/C } \\
\text { Ratio }\end{array}$ \\
\hline \multirow{5}{*}{ Herbicide } & Increase in cow numbers & $(\%)$ & $\left(\$ \mathrm{ha}^{-1}\right)$ & \\
& No Increase in cow numbers & & 13.2 & 2.3 \\
& No Increase in cow numbers & 5 & 9.0 & 1.9 \\
Burn & Increase cow numbers & 10 & 9.5 & 6.8 \\
& No Increase in cow numbers & 0 & 18.0 & 6.2 \\
& No Increase in cow numbers & 5 & 16.0 & 6.4 \\
\hline
\end{tabular}


involving prescribed burning in this paper refer only to those circumstances where fine fuel amount is $\geq 1700-\mathrm{kg} \mathrm{ha}^{-1} \mathrm{yr}^{-1}$ (Ansley and Jacoby 1998). In circumstances where the fuel is less than this, due to the presence of brush or poor herbaceous composition, low site production potential, drought or grazing, the use of prescribed fire to topkill the brush is not possible. In these circumstances other means, such as herbicide application or mechanical brush removal, are usually necessary to restore herbaceous productivity before fire is a viable management option.

Table 4. Consequence of varying the cost of treating mesquite with root-killing herbicides or prescribed fire on net present value $(\mathrm{NPV})$ and benefit/cost $(\mathrm{B} / \mathrm{C})$ ratio.

\begin{tabular}{lrrrr}
\hline \hline Treatment & Treatment Cost & NPV & $\begin{array}{c}\text { B/C } \\
\text { Ratio }\end{array}$ \\
& Initial & \multicolumn{3}{c}{ Follow-up } \\
\hline \multirow{3}{*}{ Herbicide } & 56.81 & 6.18 & 13.2 & 2.3 \\
& 41.99 & 6.18 & 15.8 & 3.0 \\
& 29.64 & 6.18 & 17.9 & 4.1 \\
Burn & 12.35 & 6.18 & 14.9 & 3.4 \\
& 6.18 & 6.18 & 18.0 & 6.8 \\
& 4.94 & 4.94 & 18.6 & 8.6 \\
\hline
\end{tabular}

Table 4 illustrates the consequence of reducing the cost of applying herbicides. The cost of the herbicide has to halve to $\$ 30 \mathrm{ha}^{-1}$ before net present values for the herbicide are competitive with $\$ 6$ or $\$ 12$ $\mathrm{ha}^{-1}$ for prescribed burns. However, even at an herbicide cost of $\$ 30 \mathrm{ha}^{-1}$, benefit/cost ratios for burns were greater even at twice the cost $\left(\$ 12 \mathrm{ha}^{-1}\right)$ of burning measured in field experiments. This analysis showed more sensitivity to cost of herbicide than to treatment longevity following herbicide treatment (compare Table 2 and Table 4).

The cost of adding fences to facilitate pre- and post-burn deferment decreased net present value a small amount if electric fencing is used (Table 5), but using 5wire fencing reduced economic benefits considerably. In both cases, economic returns are decreased considerably more when herbicides were used instead of fire. Even if a no-fence herbicide scenario is compared with a 5-wire-8-pasture system, the prescribed burning scenario had a greater net present value than the herbicide option. The most likely and economically rational scenario, burning with a 4pasture or 8-pasture system without incurring any fencing costs, has considerably

Table 5. Effect on net present value (NPV) and benefit/cost (B/C) ratio of treating mesquite with root-killing herbicides or prescribed fire if fences have to be erected.

\begin{tabular}{|c|c|c|c|c|c|c|c|}
\hline \multirow[t]{2}{*}{ Treatment } & \multirow{2}{*}{$\begin{array}{l}\text { Type of } \\
\text { Fence }\end{array}$} & \multicolumn{2}{|c|}{ Cost } & \multicolumn{2}{|c|}{4 pasture system } & \multicolumn{2}{|c|}{8 pasture system } \\
\hline & & $\begin{array}{l}4 \text { pasture } \\
\text { system }\end{array}$ & $\begin{array}{l}8 \text { pasture } \\
\text { system }\end{array}$ & NPV & $\begin{array}{c}\mathrm{B} / \mathrm{C} \\
\text { Ratio }\end{array}$ & NPV & $\begin{array}{l}\mathrm{B} / \mathrm{C} \\
\text { Ratio }\end{array}$ \\
\hline & & $----(\$ 1)$ & $\left.a^{-1}\right)----$ & $\left(\$ \mathrm{ha}^{-1}\right)$ & & $\left(\$ \mathrm{ha}^{-1}\right.$ & \\
\hline \multirow[t]{3}{*}{ Herbicide } & None & 0 & 0 & 13.2 & 2.3 & 13.2 & 2.3 \\
\hline & Electric & 1.09 & 2.62 & 13.0 & 2.2 & 12.8 & 2.2 \\
\hline & 5 wire & 9.26 & 22.23 & 11.7 & 2.0 & 9.4 & 1.7 \\
\hline \multirow[t]{3}{*}{ Burn } & None & 0 & 0 & 18.0 & 6.8 & 18.0 & 6.8 \\
\hline & Electric & 1.09 & 2.62 & 17.8 & 6.5 & 17.5 & 6.0 \\
\hline & 5 wire & 9.26 & 22.23 & 16.4 & 4.5 & 14.2 & 3.1 \\
\hline
\end{tabular}

higher net present values than all herbicide alternatives considered. It should be noted, however, that mesquite density is never reduced with fire, but periodic burning should keep mesquite suppressed.

The importance of improving or decreasing wildlife income with either means of treating mesquite is presented in Table 6. Of all factors considered, net present values show by far the greatest sensitivity to variations in wildlife income. If treatment on any part of a ranch either increases or decreases wildlife income, net present values are changed markedly.

\section{Conclusions}

Over a 20 to 30 year period, not treating mesquite brush leads to levels of brush cover that reduce herbage production and hinder normal ranch functions such as gathering cattle for branding and weaning. Once this situation occurs, profitability of livestock production from rangeland is greatly reduced and a large expenditure of capital is usually required for ranchers to continue making a living with livestock.

Clay-loam range sites generally make up $40-60 \%$ of the land area in the Rolling Plains of Texas and if left untreated, there is a substantial annual increase in the aerial cover of mesquite on these areas. This

Table 6. Effect on net present value (NPV) and benefit/cost (B/C) ratio of root-killing herbicides and prescribed fire if mesquite removal reduces or improves income from wildlife.

\begin{tabular}{lcccc}
\hline \hline Treatment & \multicolumn{2}{c}{ Wildlife lease } & NPV & $\begin{array}{c}\text { B/C } \\
\text { Ratio }\end{array}$ \\
\hline & Untreated area & Treated area & \\
\hline \multirow{2}{*}{ Herbicide } & 7.41 & 7.41 & 13.2 & 2.3 \\
& 7.41 & 2.47 & {$[-12.9]$} & {$[-0.2]$} \\
& 7.41 & 12.35 & 39.4 & 4.8 \\
Burn & 7.41 & 7.41 & 18.0 & 6.8 \\
& 7.41 & 2.47 & {$[-8.2]$} & {$[-1.7]$} \\
& 7.41 & 12.35 & 44.1 & 15.3 \\
\hline
\end{tabular}

poses a significant economic burden to anyone attempting to derive a livelihood from ranching with livestock. Fire, which can be applied at a cost of about $\$ 6 \mathrm{ha}^{-1}$ or less, is less expensive than spraying with a root-killing herbicide at $\$ 42$ to $\$ 62 \mathrm{ha}^{-1}$ or mechanical clearing at $\$ 124$ to $\$ 222 \mathrm{ha}^{-1}$. Prescribed fire has an economic (net present value) advantage over broadcast application of herbicides because of the high initial cost of applying herbicides. This advantage holds even if we assume that fire performs less adequately than herbicides, including a delayed increase in herbage production 1 year after burning rather than the first year after treatment, and an improvement in carrying capacity which is less than that with herbicide treatment. Even with the lowest likely response in carrying capacity with prescribed burning, it compares very favorably in net present value terms, with the current herbicide alternative described above. If cow numbers are not increased after treating brush, burning has an even greater economic advantage over herbicide treatment than if cow numbers are increased after treatment.

The analyses indicate the economic response is most sensitive to the treatment effect on wildlife income since the added income from wildlife is assumed to account for any additional cost. Although 
fires are patchier and less effective on larger mesquite than broadcast herbicide application, this would be beneficial if wildlife were part of the equation.

The cost of herbicide would have to be less than half the current cost before it would be economically competitive with fire as a means of controlling mesquite. It should be noted that on smaller properties with less dense mesquite, the use of individual plant treatment using herbicide (Ueckert et al. 1999) might reduce the economic disparity between herbicide and fire treatments as part of a fire plan.

Even if fences have to be constructed as part as a fire plan, the net present value of the herbicide option was lower than those for realistic burning scenarios. Most ranches would be able to implement at least a 4pasture-1-herd system without any increase in fencing. In addition, grazing systems also have the potential of improving range condition (Norton 1998, Teague et al 1999) and hence primary and secondary productivity. Improving range condition applies to both herbicide and fire treatment and would further improve long-term economic benefits.

Fire is not as easy or convenient to use as chemical or mechanical treatments for controlling mesquite, but it does offer the opportunity of lowering costs substantially by substituting management for capital inputs to increase profit margins. In times of below average rainfall, burning can be very difficult or impossible to implement. Reducing stock numbers and only burning $1 / 8$ of the grazing management unit each year would help considerably in ensuring regular burns were possible in all but abnormally dry years. These analyses show that such management would be very competitive economically with any large-scale herbicide treatment on large ranches. Fire cannot replace herbicides since there are times when herbicides are the only option. This analysis indicates that there is an economic advantage to using fire wherever possible and restricting use of herbicides to those instances that fire is not a viable option. Diversification in the form of adding or increasing wildlife income appears to offer the highest economic return whichever method of mesquite treatment is used.

\section{Literature Cited}

Angell, R.F., J.W. Stuth, and D.L. Drawe. 1986. Diets and liveweight changes of cattle grazing fall burned gulf cordgrass. J. Range Manage. 39:233-236.
Ansley, R.J. and P.W. Jacoby. 1998. Manipulation of fire intensity to achieve mesquite management goals in north Texas, p.195-204. In: T.L. Pruden and L.A. Brennan (eds.). Fire in ecosystem management: shifting the paradigm from suppression to prescription. Tall Timbers Fire Ecology Conf. Proceedings, No. 20. Tall Timbers Research Station, Tallahassee, Fla.

Ansley, R.J., W.R. Teague, and W.E Pinchak. 1999. The cost of burning medium-sized pastures for mesquite control: data from the Kite Camp study, p.21. In: Rolling Plains Ranching Systems Report. Ed. W.R. Teague. Texas Agr. Exp. Station, Vernon Center Tech. Rep. \#99-10. Vernon, Tex.

Ansley, R.J., B. Wu, and B. Kramp. 2001. Observation: long-term increases in mesquite canopy cover in north Texas. J. Range Manage. 54:171-176.

Ansley, R.J., D.L. Jones, T.R. Tunnell, B.A. Kramp, and P.W. Jacoby. 1998. Honey mesquite canopy responses to single winter fires: relation to fine fuel, weather and fire temperature. Int. J. Wildl. Fire. 8:241-252.

Ansley, R.J., S.M. McMullen, W.E Pinchak, J.R. Conner, and W.R. Teague. 2000. Longevity of top-killing and root-killing mesquite herbicides: forage production and mesquite recruitment in areas treated 10 and 20 years ago, p. 44. In: Soc. for Range Manage. Annual Meeting, Boise, Ida

Bedunah, D.J. and R.E. Sosebee. 1984. Forage response of a mesquite-buffalograss community following range rehabilitation. J. Range Manage. 37:483-487.

Bement, R.E. 1969. A stocking-rate guide for beef production on blue-grama range. $\mathrm{J}$. Range Manage. 22:83-86.

Bernardo, D. J., G. W. Boudreau, and T. C. Bidwell. 1994. Economic tradeoffs between livestock grazing and wildlife habitat: a ranch-level analysis. Wildl. Soc. Bull. 22:393-402.

Brock, J.H., R.H. Haas, and J.C. Shaver. 1978. Zonation of herbaceous vegetation associated with honey mesquite in north central Texas, p.187-189. In: D.N. Hyder (ed.). Proc.1st Int. Rangeland Congr., Soc. Range Manage. Denver, Colo.

Dahl, B.E., R.E. Sosebee, and J.P. Goen. 1973. Influence of mesquite on grass yields. Texas Tech. Research Highlights, Lubbock, Tex. 4:19.

Dahl, B.E., R.E. Sosebee, J.P. Goen, and C.S. Brumley. 1978. Will mesquite control with 2,4,5-T enhance grass production? J. Range Manage. 31:129-131.

Fulbright, T.E. and F.S. Guthery. 1996. Mechanical manipulation of plants, $p$. 339-354. In: P.R. Krausman (ed.), Rangeland Wildlife. Soc. for Range Manage. Denver, Colo..

Gibbens R.P., C.H. Herbel, H.L. Morton, W.C. Lindemann, J.A. Ryder-White, D.B. Richman, E.W. Huddleston, W.H. Conley, C.A. Davis, J.A. Reitzel, D.M. Anderson, and A. Guiao. 1986. Some impacts of 2,4,5$\mathrm{T}$ on a mesquite duneland ecosystem in southern New Mexico: a synthesis J. Range Manage. 39:320-326.
Guthery, F.S. 1996. Upland gamebirds, p 59-69. In: P.R. Krausman (ed.). Rangeland Wildlife Soc. Range Manage., Denver, Colorado.

Hamilton, W.T., L.M. Kitchen, and C.J. Scifres. 1981. Height replacement of selected woody plants following burning or shredding. Texas. Agr. Exp. Sta. Bull. 1361. 9 pp.

Hansmire, J.A., D.L. Drawe, D.B. Wester, and C.M. Britton. 1988. Effects of winter burns on forbs and grasses of the Texas coastal prairie. Southw. Nat. 33:333-338.

Heitschmidt, R.K., R.D. Schultz, and C.J. Scifres. 1986. Herbaceous biomass dynamics and net primary production following chemical control of honey mesquite. J. Range Manage. 39:67-71.

Koerth, B.H. 1996. Chemical manipulation of plants, p. 321-337. In: P.R. Krausman (ed.). Rangeland Wildlife. Soc. Range Manage., Denver, Colo.

Lehman, V. W. 1984. Bobwhites in the Rio Grande Plain of Texas. Texas A\&M University Press, College Station, Tex. pp 247-257.

McDaniel K.C., J.H. Brock, and R.H. Haas. 1982. Changes in vegetation and grazing capacity following honey mesquite control. J. Range Manage. 35:551-557.

McDaniel, K.C., R.H. Haas, and J.H. Brock. 1978. Range condition trends following control of honey mesquite (Prosopis glandulosa var. glandulosa) on deep hardlands in north central Texas, p. 530-533. Proc $1^{\text {st }}$ Int. Rangeland Congr., Soc. Range Manage., Denver, Colo.

McGrann, J.M., N. Green, J. Parker, J. Falconer, D. Bade, and S. Ford. 1998. Beef Cattle and Forage Business Management Decision Aids. Dept. of Agr. Econ., Texas A\&M Univ., College Station, Tex.

McMullen, S.M. 2000. Economic Assessment of Forage Responses to Mesquite Control in the Rolling Plains of North Texas. MS thesis, Texas A\&M Univ., College Station, Tex.

Norton, B.E. 1998. The application of grazing management to increase sustainable livestock production. Anim. Prod. in Australia. 22:15-26.

Reardon, P.O., L.B. Merrill, and C.A. Taylor, Jr. 1978. White-tailed deer preferences and hunter success under various grazing systems. J. Range. Manage. 31:40-42.

Scifres, C.J. 1980. Brush Management. Principles and Practices for Texas and Southwest. Texas A\&M Univ. Press, College Station. 360 pp.

Scifres, C.J. and W.T. Hamilton. 1993. Prescribed burning for brushland management: The south Texas example. Texas A\&M Press, College Station, Tex.

Scifres, C.J. and B.H. Koerth. 1986. Habitat alterations in mixed brush from variable rate herbicide patterns. Wild. Soc. Bull. 14:345-356.

Scifres, C.J. and D.B. Polk. 1974. Vegetation response following spraying a light infestation of honey mesquite J. Range Manage. $27: 462-465$ 
Svejcar, T.J. 1989. Animal performance and diet quality as influenced by burning tallgrass prairie. J. Range Manage. 42:11-15.

Teague, W.R., T.R. Borchard, R.J. Ansley, W.E. Pinchak, J. Cox, J.K. Foy, and J.M McGrann. 1997. Sustainable management strategies for mesquite rangeland: the Waggoner Kite project. Rangelands. 19:4-8.

Teague, W.R., R.J. Ansley, J.M McGrann, and W.E. Pinchak, 1999. Developing sustainable management strategies for mesquite rangeland. Rev. Argentina. Prod. Anim. 19:37-46.
Teer, J.G. 1996. The White-tailed deer: natural history and management, p. 193-210. In: P.R. Krausman (ed.). Rangeland Wildlife. Soc. Range Manage., Denver, Colo.

Thurow, T.L., A.P. Thurow, and M.D. Garriga. 2000. Policy prospects for brush control to increase off-site water yield. J. Range Manage. 53:23-31.

Ueckert, D.N., W.A. McGinty, and U.P. Kreuter. 1999. Brush busters: marketing Prosopis management technology, p. 580-581. Proc. VI ${ }^{\text {th }}$ Int. Rangeland Congr., Soc. Range Manage., Townsville, Queensland.
Vantassell, C.W. and J.R. Conner. 1986. An economic analysis of Brush Control Practices and Grazing systems in the Rolling Plains of Texas, MP-1619. Texas Agr. Exp. Station, Texas A\&M Univ., College Station, Tex. 77843.

Workman, J.P. 1986. Range Economics. Macmillan, New York, N.Y.

Wright, H.A. and A.W. Bailey. 1982. Fire Ecology. John Wiley \& Sons. New York, N.Y.

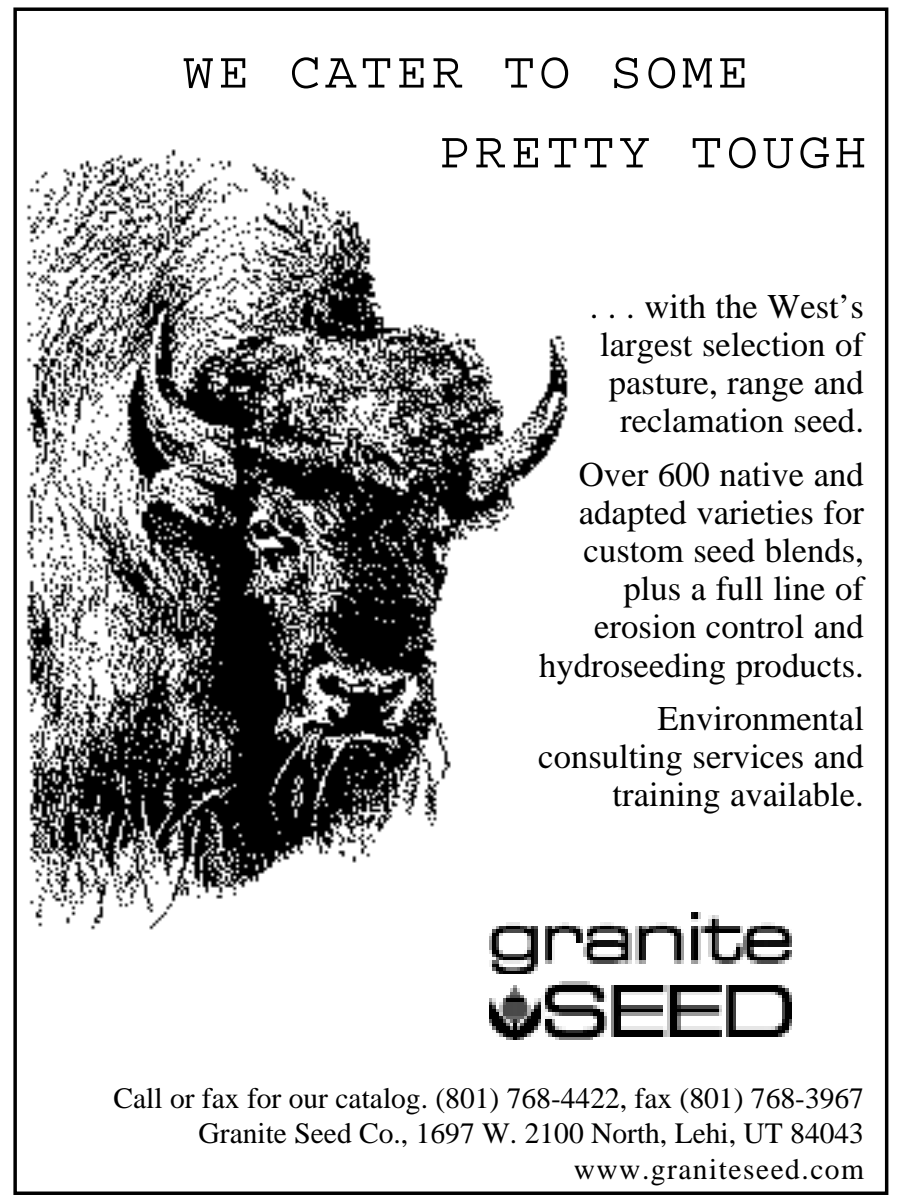

